\title{
PENINGKATAN KINERJA GURU DENGAN PEMBINAAN KEPROFESIONALAN OLEH KEPALA SEKOLAH DI SD NEGERI 118334 SEI DAUN TP. 2018/2019
}

\section{IMPROVEMENT OF TEACHER PERFORMANCE WITH THE PROFESSIONAL DEVELOPMENT BY SCHOOL HEADS IN SD NEGERI 118334 SEI DAUN} TP. 2018/2019

\author{
PINTAULI \\ SD Negeri 118334 Sei Daun Kecamatan Torgamba Labuhanbatu Selatan, Indonesia
}

\begin{abstract}
Abstrak
Penelitian ini bertujuan untuk mengetahui bentuk pembinaan keprofesional oleh Kepala sekolah dalam meningkatkan kinerja Guru di SD Negeri 118334 Sei Daun Tahun Pelajaran 2018/2019. Metode dalam penelitian ini adalah penelitian tindakan kelas dengan 2 siklus terdiri dari 4 Tahapan, perencanaan, Tindakan, Observasi, Refleksi. Subjek dalam penelitian ini adalah Guru di SD Negeri 118334 Sei Daun berjumlah 9 orang. Teknik Pengumpulan Data dalam Penelitian Ini dengan menggunakan Tes, observasi, dan Dokumentasi. Hasil Penelitian Menunjukkan pada siklus 1 hasil Tes Kinerja Guru dalam menunjukkan dengan nilai rata-rata 62,22\% guru dari 9 peserta mencapai ketuntasan klasikal. Kemudian dari 9 guru hanya 3 peserta atau $33,33 \%$ yang mencapai syarat keberhasilan, sedangkan 6 peserta atau $66,67 \%$ yang tidak mencapai keberhasilan. Sesuai dengan Indikator keberhasilan dalam pencapaian penelitian ini yaitu minimal 80. Pada siklus kedua hasil Tes Kinerja Guru mencapai nilai 91,1. Sedangkan hasil kinerja guru secara umum semua guru sudah mencapai Ketuntasan dalam mengikuti supervisi yang dilaksanakan kepala sekolah. Berdasarkan hasil analisis data yang telah dilakukan maka dapat disimpulkan bahwa terdapat peningkatan kinerja guru di SD Negeri 118334 Sei Daun Tahun Pelajaran 2018/2019 melalui pembinaan profesional oleh kepala sekolah.
\end{abstract}

Kata Kunci : Pembinaan, Supervisi, Kepala Sekolah, Kinerja Guru

\begin{abstract}
This study aims to determine professional coaching by the principal in improving the performance of teachers at SD Negeri 118334 Sei Daun in the 2018/2019 academic year. The method in this research is Classroom Action Research with 2 cycles consisting of 4 stages, planning, action, observation, reflection. The subjects in this study were 9 teachers at SD Negeri 118334 Sei Daun. Data collection techniques in this study using tests, observation, and documentation. The results showed that in cycle 1 the results of the Teacher Performance Test showed an average value of $62.22 \%$ of the 9 participants' teachers achieved classical completeness. Then from 9 teachers only 3 participants or $33.33 \%$ achieved the success requirements, while 6 participants or $66.67 \%$ did not achieve success. in accordance with the indicators of success in the achievement of this study, namely at least 80 . In the second cycle the Teacher Performance Test results reached a value of 91.1. While the results of teacher performance in general, all teachers have achieved completeness in following the supervision carried out by the principal. Based on the analysis of the data that has been analyzed, the professional guidance by the principal in improving the performance of teachers at SD Negeri 118334 Sei Daun in the 2018/2019 academic year is declared to have achieved completeness.
\end{abstract}

Keywords: Coaching, Supervision, Principal, Teacher performance 


\section{Pendahuluan}

Sekolah berperan sebagai lembaga yang memproses lulusan untuk bidang-bidang pekerjaan dalam kehidupan masyarakat secara luas.Sekolah melaksanakan kegiatan layanan belajar dimana dalam penyelenggaraannya suatu pendidikan perlu melakukan penjaminan kualitas pendidikan yang bertujuan untuk memenuhi atau melampaui Standar Nasional Pendidikan[1].

Kepala sekolah sebagai manajer akan melaksanakan fungsi manajemen yang meliputi perencanaan, pengorganisasian, pelaksanaan motivasi, memfasilitasi, pemberdayaan, mengawasi dan mengevaluasi untuk mengelola sumber daya yang ada di sekolah dalam rangka mencapai tujuan yang ditetapkan. Oleh karena itu dalam rangka memenuhi kebutuhan-kebutuhan tersebut di atas maka tugas guru sebagai profesi, meliputi mendidik, mengajar dan melatih dituntut supaya bekerja keras, cekatan, terampil, ahli, disiplin tinggi dalam meningkatkan pelaksanaan kinerjanya sebagai profesi.

Terhadap guru sendiri dengan jelas juga dituliskan dalam salah satu butir sari Kode Etik yang berbunyi "Guru menciptakan suasana sekolah sebaik-baiknya yang menunjang keberhasilannya proses belajar mengajar". Oleh sebab itu, guru harus aktif mengusahakan suasana yang baik itu dengan berbagai cara, baik dengan penggunaan metode mengajar yang sesuai, maupun dengan penyediaan alat belajar yang cukup, serta pengaturan organisasi kelas yang disiplin, ataupun pendekatan lainnya yang diperlukan[2].

Kegiatan supervisi pendidikan memiliki beragam fungsi.Supervisi pendidikan dapat terlaksana dengan baik, fungsi-fungsinya mampu diterapkan dengan baik pula. Fungsi kegiatan supervisi pendidikan dirinci sebagai berikut:

1) Mengkoordinasi semua usaha sekolah

2) Melengkapi kepemimpinan sekolah

3) Memperluas pengalaman guru-guru

4) Menstimulasi usaha-usaha yang kreatif

5) Memberikan fasilitas dan penilaian yang terus-menerus

6) Menganalisis situasi belajar dan mengajar

7) Memberikan pengetahuan dan keterampilan kepada setiap anggota staf

8) Mengintegrasi tujuan pendidikan dan membantu meningkatkan kemampuan guru-guru dalam mengajar[3].

Kepala sekolah adalah "seorang tenaga profesional yang diberikan tugas untuk memimpin suatu sekolah dimana diselenggarakan proses belajar mengajar." Sebagai seorang pemimpin, kepala sekolah juga harus dapat menjadi penengah dan sumber informasi serta sebagai pemecah masalah yang terjadi di sekolah yang dipimpin[4].

Profesional adalah "kesanggupan atau kecakapan guru dalam menciptakan suasana komunikasi yang edukatif antara guru dengan peserta didik yang mencakup suasana kognitif, afektif dan psikomotorik sebagai upaya mempelajari sesuatu berdasarkan perencanaan sampai dengan tahap evaluasi dan tindak lanjut agar mencapai tujuan pengajaran[5].

Pada observasi yang dilakukan oleh peneliti di SD Negeri No. 118334 Sei Daun Kecamatan Torgamba Kabupaten Labuhanbatu Selatan didapatkan temuan bahwa kinerja Guru dalam melakukan tugasnya di sekolah tersebut dinilai belum memiliki Profesional dalam meningkatkan kualitas pembelajaran. Pelaksanaan supervisi yang dilakukan oleh Kepala Sekolah belum maksimal.Sementara para guru untuk menjadi guru yang professional belum memiliki kompetensi dalam memningkatkan kualitas pembelajaran, misalnya belum adanya kesadaran dalam membuat administrasi pembelajaran. Berdasarkan uraian permasalahan di atas maka peneliti akan meneliti Pembinaan kepala sekolah melalui supervisi kepala sekolah dalam meningkatkan kinerja Guru di SD Negeri No. 118334 Sei Daun Kecamatan Torgamba Kabupaten Labuhanbatu SelatanTahun Pelajaran $2018 / 2019$

\section{Metode Penelitian}

Penelitian ini adalah penelitian tindakan sekolah (PTS), karena ingin menerapkan Pembinaan Kepala Sekolah melalui Supervisi untuk meningkatkan kinerja Guru di SD Negeri 1118334 Sei Daun. subyek penelitian ini adalah Guru di sekolah binaan pada SD Negeri 118334 Sei Daun yang berjumlah 9 orang yang terdiri dari Guru PNS dan Non PNS. Penelitian ini dilaksanakan dengan 2 siklus dengan 4 Tahapan perencanaan, Tindakan, Observasi, Refleksi.Teknik Pengumpulan Data dengan menggunakan Tes, Observasi dan Dokumentasi. 
Hal : $52-57$

\section{Hasil Penelitian dan Pembahasan} Hasil Penelitian

Penelitian ini bertujuan untuk mengetahui dan mendeskripsikan pembinaan profesional oleh kepala sekolah dalam meningkatkan kinerja guru Sekolah Dasar Negeri 118334 Sei Daun Kecamatan Torgamba Kabupaten Labuhanbatu Selatan. Variabel yang diteliti dalam penelitian ini mengenai pembinaan profesional oleh kepala sekolah dalam meningkatkan kinerja guru Sekolah Dasar Negeri 118334 Sei Daun yang meliputi variabel yaitu jenis pembinaan guru.

Tabel 1. Hasil Tes Siklus 1 Kinerja Guru SD Negeri 118334 Sei Daun

\begin{tabular}{|c|c|c|c|c|c|c|c|c|}
\hline \multirow{2}{*}{$\begin{array}{l}\text { No } \\
\text { Urut }\end{array}$} & \multirow[b]{2}{*}{ Responden } & \multicolumn{5}{|c|}{ Skor } & \multirow[b]{2}{*}{ Nilai } & \multirow[b]{2}{*}{ Ket } \\
\hline & & 1 & 2 & 3 & 4 & 5 & & \\
\hline 1 & $\begin{array}{l}\text { KASMIRAH, S.Pd } \\
\text { NIP. } 196704281993022001\end{array}$ & 2 & 2 & 2 & 0 & 2 & 80 & Baik \\
\hline 2 & $\begin{array}{l}\text { MARTA SILVERIA, S.Pd } \\
\text { NIP. } 196603031994032004\end{array}$ & 2 & 0 & 0 & 2 & 2 & 60 & Kurang \\
\hline 3 & $\begin{array}{l}\text { SRI NURUL WIDIAWATI,S.Pd } \\
\text { NIP. } 198508102011012011\end{array}$ & 2 & 0 & 0 & 0 & 2 & 80 & Baik \\
\hline 4 & $\begin{array}{l}\text { RAYA SIMBOLON, S.Pd } \\
\text { NIP. } 196807252012122002\end{array}$ & 2 & 0 & 0 & 2 & 2 & 60 & Kurang \\
\hline 5 & SEPRIANTI BATUBARA, S.Pd & 2 & 0 & 0 & 2 & 0 & 40 & kurang \\
\hline 6 & HIDAYATI, S.Pd & 2 & 2 & 0 & 0 & 2 & 60 & Kurang \\
\hline 7 & APRILIES PASARIBU & 2 & 2 & 0 & 2 & 2 & 60 & Kurang \\
\hline 8 & FAROSI KRISTINA ZENDRATO, S.Pd & 2 & 0 & 2 & 0 & 0 & 40 & Kurang \\
\hline 9 & $\begin{array}{l}\text { TIAMAR MARPAUNG, S.Pd } \\
\text { NIP. } 196107291995092001\end{array}$ & 2 & 0 & 2 & 2 & 2 & 80 & Baik \\
\hline & Jumlah & & & & & & 560 & \\
\hline & Rata-rata & & & & & & $62.22 \%$ & \\
\hline & Keberhasilan & & & 3.33 & & & & \\
\hline
\end{tabular}

Dengan memperhatikan tabel tersebut maka dapat diambil kesimpulan bahwa kemampuan guru dalam meningkatkan kinerja Guru dengan Pembinaan Oleh kepala sekolah masih belum memuaskan. Berdasarkan hasil tabel di atas menunjukkan dengan nilai rata-rata $62,22 \%$ guru dari 9 peserta mencapai ketuntasan klasikal. Kemudian dari 9 guru hanya 3 peserta atau 33,33\% yang mencapai syarat keberhasilan, sedangkan 6 peserta atau $66,67 \%$ yang tidak mencapai keberhasilan.

Tabel 2. Hasil Pengamatan Siklus 1 Kinerja Guru SD Negeri 118334 Sei Daun

\begin{tabular}{|c|l|c|c|c|c|}
\hline No & Sub Variabel & $\begin{array}{c}\text { Skor } \\
\text { Perolehan }\end{array}$ & Skor ideal & $\begin{array}{c}\text { Persentase } \\
\mathbf{( 1 0 0 \% )}\end{array}$ & Kategori \\
\hline 1 & Jenis Pembinaan & 18782 & 26208 & $71.7 \%$ & Baik \\
\hline 2 & $\begin{array}{l}\text { Teknik/Cara } \\
\text { Pembinaan }\end{array}$ & 6518 & 8736 & $74.6 \%$ & Baik \\
\hline & Total & 23823 & 34944 & $68.2 \%$ & Baik \\
\hline
\end{tabular}

Dari tabel di atas menunjukkan bahwa pembinaan professional oleh kepala sekolah dalam meningkatkan kinerja guru melalui supervise di SD Negeri 118334 Sei Daun yang dilihat dari jenis pembinaan berada dalam kategori baik dengan perolehan skor 18782 (71,7\%). Sementara pembinaan professional oleh kepala sekolah dalam meningkatkan kinerja guru SD Negeri 118334 Sei Daun dilihat dari teknik/cara pembinaan juga berada pada kategori baik dengan perolehan skor $6518(74,6 \%)$. Dengan demikian secara keseluruhan pembinaan profesional oleh kepala sekolah dalam meningkatkan kinerja guru SD Negeri 118334 Sei Daun berada dalam kategori baik (68,2\%). 
Hal : $52-57$

Tabel 3. Hasil Tes Siklus 2 Kinerja Guru SD Negeri 118334 Sei Daun

\begin{tabular}{|c|c|c|c|c|c|c|c|c|}
\hline \multirow{2}{*}{$\begin{array}{l}\text { No } \\
\text { Urut }\end{array}$} & \multirow[b]{2}{*}{ Responden } & \multicolumn{5}{|c|}{ Skor } & \multirow[b]{2}{*}{ Nilai } & \multirow[b]{2}{*}{ Ket } \\
\hline & & 1 & 2 & 3 & 4 & 5 & & \\
\hline 1 & $\begin{array}{l}\text { KASMIRAH, S.Pd } \\
\text { NIP. } 196704281993022001\end{array}$ & 2 & 2 & 2 & 2 & 2 & 100 & $\begin{array}{l}\text { Sangat } \\
\text { Baik }\end{array}$ \\
\hline 2 & $\begin{array}{l}\text { MARTA SILVERIA, S.Pd } \\
\text { NIP. } 196603031994032004\end{array}$ & 2 & 2 & 2 & 2 & 2 & 100 & $\begin{array}{l}\text { Sangat } \\
\text { Baik }\end{array}$ \\
\hline 3 & $\begin{array}{l}\text { SRI NURUL WIDIAWATI,S.Pd } \\
\text { NIP. } 198508102011012011\end{array}$ & 2 & 2 & 0 & 2 & 2 & 80 & Baik \\
\hline 4 & $\begin{array}{l}\text { RAYA SIMBOLON, S.Pd } \\
\text { NIP. } 196807252012122002\end{array}$ & 2 & 2 & 2 & 2 & 2 & 100 & $\begin{array}{l}\text { Sangat } \\
\text { Baik }\end{array}$ \\
\hline 5 & SEPRIANTI BATUBARA, S.Pd & 2 & 2 & 2 & 2 & 0 & 80 & Baik \\
\hline 6 & HIDAYATI, S.Pd & 2 & 2 & 0 & 2 & 2 & 80 & Baik \\
\hline 7 & APRILIES PASARIBU & 2 & 2 & 0 & 2 & 2 & 80 & Baik \\
\hline 8 & FAROSI KRISTINA ZENDRATO, S.Pd & 2 & 2 & 2 & 2 & 2 & 100 & $\begin{array}{l}\text { Sangat } \\
\text { Baik }\end{array}$ \\
\hline 9 & $\begin{array}{l}\text { TIAMAR MARPAUNG, S.Pd } \\
\text { NIP. } 196107291995092001\end{array}$ & 2 & 2 & 2 & 2 & 2 & 100 & $\begin{array}{l}\text { Sangat } \\
\text { Baik }\end{array}$ \\
\hline & Jumlah & & & & & & 560 & \\
\hline & Rata-rata & & & & & & $91,1 \%$ & \\
\hline & Keberhasilan & & & 100 & & & & \\
\hline
\end{tabular}

Dari tabel di atas setelah data dianalisis siklus kedua menunjukkan bahwa pembinaan professional oleh kepala sekolah dalam meningkatkan kinerja guru melalui supervise di SD Negeri 118334 Sei Daun yang dilihat dari jenis pembinaan berada dalam kategori baik dengan perolehan skor $91,1 \%$.Dengan demikian secara keseluruhan pembinaan profesional oleh kepala sekolah dalam meningkatkan kinerja guru SD Negeri 118334 Sei Daun berada dalam kategori Sangat Baik.Berdasarkan hasil tersebut maka peneliti berhak untuk melakukan penelitian sampai tahapan siklus kedua dinyatakan berhenti dikarenakan hasil kinerja guru SD Negeri 118334 Sei Daun sudah memenuhi Ketuntasan.

Gambaran jenis pembinaan profesional oleh kepala sekolah dalam meningkatkan kinerja guru SD Negeri 118334 Sei Daun dilihat dari supervisi pengajaran dapat disajikan pada tabel berikut:

Table 4. Hasil Observasi kegaiatan Supervisi Guru oleh kepala sekolah

\begin{tabular}{|l|l|c|c|}
\hline No & \multicolumn{1}{|c|}{ Indikator } & $\begin{array}{c}\text { Persentase } \\
(\%)\end{array}$ & kategori \\
\hline 1 & $\begin{array}{l}\text { Membimbing guru dalam merumuskan tujuan } \\
\text { pembelajaran }\end{array}$ & 77,5 & baik \\
\hline 2 & $\begin{array}{l}\text { Mendiskusikan permasalahan terkait } \\
\text { penyusunan materi pokok pelajaran secara } \\
\text { rinci }\end{array}$ & 75,2 & baik \\
\hline 3 & $\begin{array}{l}\text { Mendiskusikan permasalahan terkait pemilihan } \\
\text { penggunaan metode dan strategi } \\
\text { pembelajaran yang efektif }\end{array}$ & 78,8 & baik \\
\hline 4 & $\begin{array}{l}\text { Mendiskusikan permasalahan berkaitan } \\
\text { pemilihan alat/bahan/sumber belajar }\end{array}$ & 75,5 & \\
\hline
\end{tabular}




\begin{tabular}{|l|l|c|c|}
\hline 5 & $\begin{array}{l}\text { Membimbing guru dalam menentukan } \\
\text { penilaian atau evaluasi proses dan hasil } \\
\text { belajar }\end{array}$ & 78,5 & baik \\
\hline 6 & $\begin{array}{l}\text { Membimbing guru dalam mempersiapkan } \\
\text { perangkat pembelajaran }\end{array}$ & 70,5 & baik \\
\hline 7 & $\begin{array}{l}\text { Membimbing guru dalam persiapan } \\
\text { pembelajaran }\end{array}$ & 76,5 & baik \\
\hline 8 & $\begin{array}{l}\text { Membimbing guru dalam membuka } \\
\text { pembelajaran }\end{array}$ & 80 & baik \\
\hline 9 & $\begin{array}{l}\text { Membimbing guru dalam penguasaan materi } \\
\text { pembelajaran }\end{array}$ & 77,8 & baik \\
\hline 10 & $\begin{array}{l}\text { Membimbing guru dalam menggunakan } \\
\text { pendekatan atau strategi pembelajaran }\end{array}$ & 76,6 & baik \\
\hline 11 & $\begin{array}{l}\text { Membimbing guru dalam pemanfaatan sumber } \\
\text { belajar atau media pembelajaran }\end{array}$ & 78,5 & baik \\
\hline 12 & $\begin{array}{l}\text { Membimbing guru dalam melibatkan siswa } \\
\text { dalam pembelajaran }\end{array}$ & 75,4 & $\begin{array}{l}\text { Membimbing guru dalam penggunaan bahasa } \\
\text { dalam pembalajaran }\end{array}$ \\
\hline 13 & $\begin{array}{l}\text { Membimbing guru dalam menilai hasil belajar } \\
\text { siswa }\end{array}$ & 72,5 & 78,4 \\
\hline & \multicolumn{1}{|c|}{ Rata - Rata Hasil } & $78,7 \%$ & \\
\hline
\end{tabular}

Berdasarkan analisis skor secara keseluruhan, dapat diketahui bahwa jenis pembinaan profesional oleh kepala sekolah dalam meningkatkan kinerja guru Sekolah Dasar Negeri 118334 Sei Daun dilihat dari supervisi pengajaran termasuk dalam kategori baik dengan persentase sebesar $(78,7 \%)$. Dari 14 indikator, seluruhnya termasuk dalam kategori baik.Dengan demikian jenis pembinaan profesional oleh kepala sekolah dalam meningkatkan kinerja guru Sekolah Dasar Negeri 118334 Sei Daun dilihat dari supervisi pengajaran sudah baik.

Tabel 5. Hasil Tes siklus 1 dan 2 Kinerja Guru SD Negeri 118334 Sei Daun 2018/2019

\begin{tabular}{|c|c|c|c|c|}
\hline No & Tahapan & Hasil Tes & Keberhasilan & Kategori \\
\hline 1 & Siklus 1 & $62,2 \%$ & 3 Guru $(33,33 \%)$ & Kurang Baik \\
\hline 2 & Siklus 2 & $91,1 \%$ & 9 Guru $(100 \%)$ & Sangat Baik \\
\hline
\end{tabular}

\section{Pembahasan}

Berdasarkan hasil penelitian menunjukkan bahwa pembinaan profesional oleh kepala sekolah dalam meningkatkan kinerja guru SD Negeri 118334 Sei Daundalam siklus 1 dapat dilihat bahwa hasil Tes Kinerja Guru dalam kategori kurang Baik (62,2\%). Dari 9 Guru ketuntasan Guru dalam mekasanakan Supervisi Kepala sekolah hanya 3 Guru yang mencapai Ketuntasan. Berdasarkan hasil siklus 1 dapat dilihat bahwasanya beberapa kekurangan pada siklus 1 dapay diperbaiki pada saat Supervisi siklus 2.

Pembinaan profesional melalui supervise siklus 2 dapat dilihat bahwasanya ketuntasan kinerja Guru mencapai $91,1 \%$. Sedangkan ketuntasan kinerja guru dalam melaksanakan Supervisi mencapai $100 \%$ atau 9 Guru sudah bias memperbaiki kinerja pada semester genap dalam melaksanakan Pembelajaran di SD Negeri 118334 Sei Daun Tahun Pelajaran 2018/2019. Pembinaan profesional oleh kepala sekolah dalam meningkatkan kinerja guru SD Negeri 118334 Sei Daun tergolong katagori Sangat baik. Hal ini berarti pembinaan profesional oleh kepala sekolah dalam meningkatkan kinerja guru SD Negeri 118334 Sei Daun sudah berjalan dengan baik dan sesuai dengan harapan peneliti dalam hal ini Kepala Sekolah dalam melaksanakan Penelitian Tindakan Sekolah.

Teknik atau cara kepala sekolah melaksanakan kegiatan pembinaan dalam meningkatkan kinerja guru secara kelompok dibagi menjadi empat jenis kegiatan yaitu diskusi kelompok, demonstrasi mengajar, penataran atau seminar, dan rapat guru. Berdasarkan keterangan dari kepala sekolah diperoleh informasi bahwa dalam kegiatan diskusi kelompok kepala sekolah memberikan kesempatan kepada guru mengemukakan, pendapat, saran, atau kritik yang konstruktif bagi pengembangan Proses Belajar Mengajar. Biasanya kegiatan diskusi kelompok berlangasung secara 
Hal : $52-57$

spontan dan tidak formal, sehingga guru dapat dengan mudah mengemukakan permasalahan yang dihadapi selama proses belajar mengajar.

Pembinaan oleh kepala sekolah dalam meningkatkan kinerja guru melalui kegiatan demonstrasi mengajar juga dilakukan oleh kepala sekolah untuk meningkatkan kinerja guru dalam proses pembeljaran. Biasanya dalam kegiatan demonstrasi mengajar guru mengamati secara langsung bagaimana kepala sekolah memberikan contoh caracara mengajar yang baik dan benar, sehingga nantinya guru dapat mempraktikkan kembali kepada peserta didik.

\section{Kesimpulan}

Berdasarkan hasil analisis data yang telah dianalisis maka kesimpulan adalam penelitian ini dalam pembinaan Kepala Sekolah dalam meningkatkan kinerja Guru SD Negeri 118334 Sei Daun melalui Supervisi Maka hasil penelitian siklus 1 menunjukkan bahwa pembinaan profesional oleh kepala sekolah dalam meningkatkan kinerja dalam kategori Kurang Baik (62,2\%). Sedangkan Pembinaan profesional pada siklus 2 dapat dilihat bahwasanya pembinaan Kepala Sekolah dalam meningkatkan kinerja Guru SD Negeri 118334 Sei Daun melalui Supervisi tersebut dapat dilihat dari jenis pembinaan yang dalam kategori sangat baik $(91,1 \%)$.Berdasarkan hasil siklus kedua maka pembinaan Kepala sekolah dalam meningkatkan kinerja Guru di SD Negeri 118334 Sei Daun melalui Supervisi Kepala Sekolah dinyatakan berhasil dan sudah Mencapai nilai Ketuntasan seperti yang diharapkan.

Berdasarkan pada hasil penelitian, pembahasan, dan kesimpulan tersebut maka peneliti dapat memberikan saran-saran sebagai berikut: (1) Sebaiknya kepala sekolah lebih meningkatkan jenis pembinaan guru terutama melalui supervisi pengajaran, Disiplin, dan Tugas tanggung jawab sebagai Guru; (2) Bagi peneliti selanjutnya hendaknya hasil penelitian ini dapat menjadi bahan pertimbangan dan dapat melanjutkan penelitian tidak hanya pada sub variabel jenis pembinaan dan teknik pembinaan tetapi dengan mengembangkan sub variabel dan indikator yang lebih luas seperti konfrensi dan lokakarya, organisasi profesi, pendidikan tambahan dan kegiatan membaca.

\section{Daftar Pustaka}

[1] Hamdani. 2011. Strategi Belajar Mengajar. Bandung : Pustaka Setia.

[2] Akhmad Sudrajat. 2008. Pengertian Pendekatan, Strategi, Metode, Teknik dan. Model Pembelajaran. Bandung : Sinar Baru Algensindo.

[3] Sahertian, Piet A. 2000. Konsep Dasar dan Teknik Supervisi Akademik. Jakarta: Bineka Cipta.

[4] Wahjosumidjo. 2002. Kepemimpinan Kepala Sekolah. Jakarta: PT. Raja. Grafindo Persada.

[5] Suryosubroto.(2004). Prestasi Belajar Mengajar di Sekolah. Jakarta: Rineka Cipta 